\title{
Mine Waste-Based Next Generation Bricks: A Case Study of Iron Ore Tailings, Red Mudand GGBS Utilization in Bricks
}

\author{
M. Beulah, ${ }^{1}$ M. R. Sudhir, ${ }^{1}$ Mothi Krishna Mohan, ${ }^{2}$ G. Gayathri, ${ }^{3}$ and Deekshith Jain $\mathbb{D}^{4}$ \\ ${ }^{1}$ Department of Civil Engineering, School of Engineering \& Technology, CHRIST (Deemed to Be University), \\ Bangalore, Karnataka, India \\ ${ }^{2}$ Department of Science and Humanities, CHRIST (Deemed to Be University), Bangalore, Karnataka, India \\ ${ }^{3}$ Department of Civil Engineering, School of Engineering, ACS College of Engineering, Bangalore, Karnataka, India \\ ${ }^{4}$ Department of Construction Technology and Management, Blue Hora University, Blue Hora, Ethiopia
}

Correspondence should be addressed to Deekshith Jain; deekshith.jain@bhu.edu.et

Received 29 July 2021; Revised 11 September 2021; Accepted 5 October 2021; Published 18 October 2021

Academic Editor: Kaushik Kumar

Copyright (c) $2021 \mathrm{M}$. Beulah et al. This is an open access article distributed under the Creative Commons Attribution License, which permits unrestricted use, distribution, and reproduction in any medium, provided the original work is properly cited.

\begin{abstract}
Utilization of mine wastes as a building material in the construction industry surmises to environmental and sustainable concepts in civil engineering. The potential environmental threat posed by mining wastes, as well as a growing societal awareness of the need to effectively treat mining wastes, has elevated the subject importance. The present research proposes a method of producing bricks that is both cost effective and environmentally benign. The research is based on the geopolymerization, known to save energy by obviating high-temperature kiln firing and lowering greenhouse gas emissions. The methodology encompasses the mixing of red mud and iron ore tailings in the range of $90 \%$ to $50 \%$ with a decrement of $10 \%$ with GGBS in the range of $10 \%$ to $50 \%$ with an increment of $10 \%$. The raw materials and the developed composites have been tested as per Indian and ASTM standards.In addition to tests pertaining to the physical and mechanical properties, XRF, XRD, and SEM tests have been performed for examining various related issues. Based on the result analysis, the compressive strength values showed noticeable differences in case of IOT and red mud bricks with IOT-based bricks showing better compressive strengths.
\end{abstract}

\section{Introduction}

Industrialization and urbanization have resulted in the generation of substantial quantities of industrial wastes, which has the potential to significantly contaminate the environment. The tremendous usage of clay for conventional bricks has led to its depletion. The difficulty in disposing of these primarily created wastes is a major source of concern. To safeguard the natural resources, it would be preferable to use these industrial wastes to make a sustainable building material based on green technology [1]. The characterization and the treatment of residue is a part of mining waste management. Previous literature has proven the viability of utilizing materials such as "fly ash and GGBS," as well as mining material as long-term infrastructure materials [2].
Brick manufacture by blending industrial wastes such as fly ash, GGBS, and slag sand with $8 \mathrm{M}$ and $10 \mathrm{M}$ geopolymer binder were used to produce high-strength bricks of $25.30 \mathrm{Mpa}$ [3]. IOT has also proven to have potential as aggregates in concrete [4-6]. Studies have reported the method of geopolymerization to make iron ore tailings bricks to attain a compressive strength of $50 \mathrm{MPa}$ by curing at $80^{\circ} \mathrm{C}$ [7]. The traditional method of making red mudGGBS bricks by firing has attained a compressive strength of $7.56 \mathrm{MPa}$ [8]. The study has proven the potential use of red mud manufacturing brick as substitute up to $25 \%$ to clay [9]. Studies have proved that lightweight foamed bricks can be made from red mud, and these bricks can be envisaged in urban development activities as partition walls in multistoried buildings which lowers the total weight of the wall, 
the foundation, and the construction cost [10]. The study has proven that the red mud-fly ash-based geopolymer coating to concrete blocks has increased the strength, durability, and thermal stability of blocks with the increment in morality of $6 \mathrm{M}$ and 12M [11]. United States Patent 3886244 highlights a method of making burnt bricks in which $50-90 \%$ red mud is of mixed clay and water fixing agent [12]. At CBRI, efforts have also been undertaken to integrate a small proportion of lime in red mud and compress the mix in the form of a brick at ideal moisture content in order to test their strength and stability to the erosive action of water [13]. The possible use of red mud in the building industry as artificial structural elements, such as enormous bricks, was investigated using geopolymerization procedure to synthesis the inorganic polymer materials [14]. Jamaica Bauxite Institute and the University of Toronto have conducted the studies to make red mud bricks for low-cost housing [15]. The ideal percentage of red mud used to replace cement in concrete is $10 \%$ which has not shown significant adverse influence on the strength of concrete [16]. The studies have proven the combination of red mud, fly ash, and lime for fired and unfired bricks to be an ideal brick material $[17,18]$. Red mud has also proven to be a suitable material for high-grade base material, filling material, and for embankment [19-22]. Many researchers have found the red mud to be a potential pozzolanic material [23-25]. The study of the blend of IOT and red mud has proven that the bricks produced are highstrength bricks as evidenced by the research [26].

1.1. Significance of the Research. The brick masonry is considered to be one of the ancient building techniques. The extreme usage of brick as a construction material has led to various detrimental effects on the ecological systems in the form of groundwater pollution, soil erosion, etc. In order to contain this, there is an overwhelming need for adopting the industrial waste products.

India is the one of the world's biggest iron ore and aluminum producers. These mining industries produce large amounts of wastes which cause landfills. Industries are facing a major challenge to address these mining waste disposals, as it has contaminated both the soil and the ground water. Figures 1 and 2 show the mining sectors of iron ore and aluminum in India, which produces nearly 18 million tons of iron ore tailings and more than four million tons of red mud. These waste materials have been promising as value-added building materials and will significantly contribute to the global efforts in reducing natural clay depletion.

The present study showcases the potential of using iron ore tailings and red mud with GGBS by geopolymerization for the production of eco-friendly bricks which can serve as structural and nonstructural elements.

\section{Materials and Methodology}

\subsection{Materials}

2.1.1. Iron Ore Tailings and Red mud. The mine wastes used in the study for preparation of the bricks were iron ore tailings from BNSIspat Bellary, red mud from Hindalco,

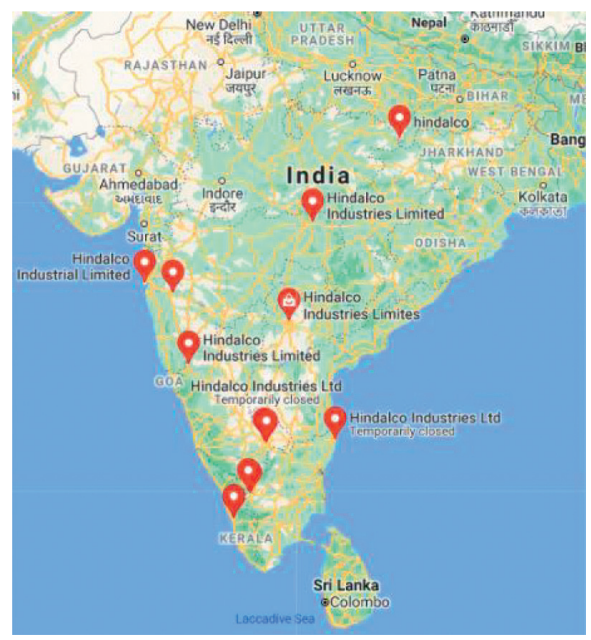

FIgURE 1: Location of red mud mines.

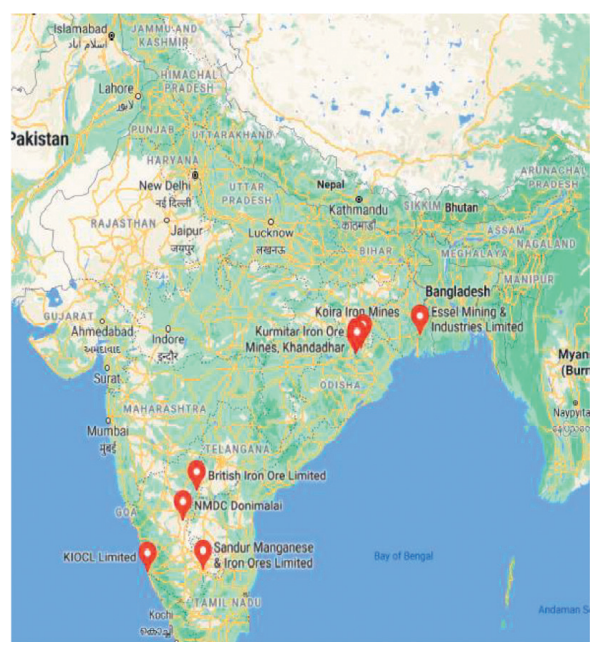

Figure 2: Location of iron ore tailing mines.

GGBS, and geopolymer chemicals. Minimal material processing was carried out on these materials used for the manufacturing of bricks.

Red mud is a bauxite ore with a mean particle size of 36.94 microns, a 50 percent particle size of 21.65 microns, and surface area of $0.58 \mathrm{~m}^{2} / \mathrm{gm}$. Similarly, IOT has a mean particle size of 22.84 microns and 50 percent particle size of 17.88 microns, with a surface area of $0.59 \mathrm{~m}^{2} / \mathrm{gm}$. Figures 3 and 4 represent the particle size distribution of red mud and IOT.

2.1.2. Geopolymer. Geopolymers are inorganic, typically ceramic, aluminosilicates forming long range, and covalently bonded noncrystalline networks. Geopolymerisation is a process of transforming aluminosilicate raw material into covalently bonded 3D network [-Si-O-Al-O-] n-bonds. Here, the synthesis of chemically integrated minerals takes place. In the present study, the geopolymerization formed by sodium hydroxide and sodium silicate involving $8 \mathrm{M}$ (molarity) of $\mathrm{NaOH}$ has been considered. 


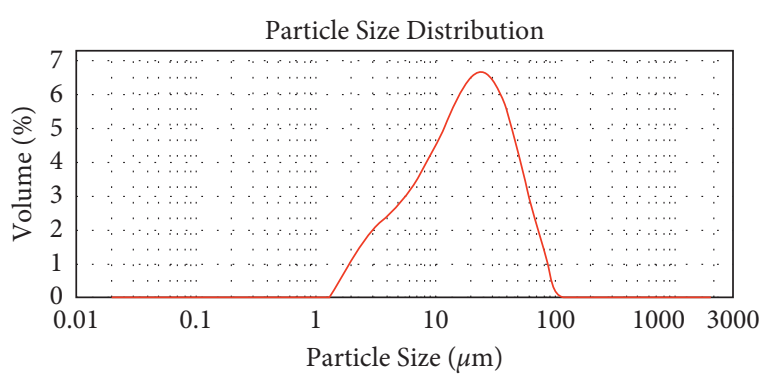

Figure 3: Particle size distribution of red Mud.

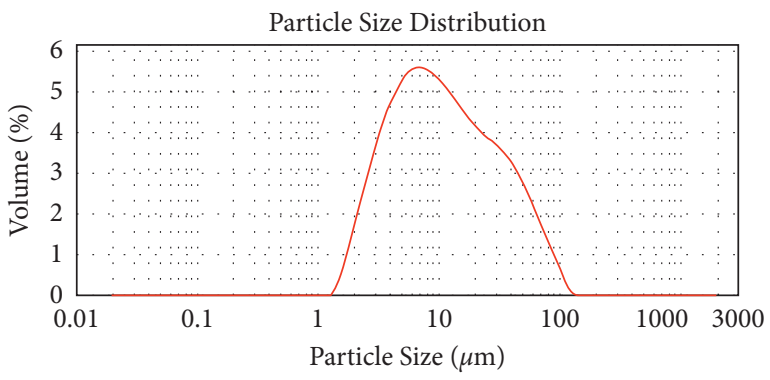

Figure 4: Particle size distribution of iron ore tailings.

From Table 1, it was observed that the primary components of red mud and IOT were $\mathrm{SiO}_{2}, \mathrm{Fe}_{2} \mathrm{O}_{3}$, and $\mathrm{Al}_{2} \mathrm{O}_{3}$. The two main components of GGBS were $\mathrm{CaO}, \mathrm{TiO}_{2}$, and $\mathrm{SiO}_{2}$. The variations of these principal components $\mathrm{SiO}_{2}$, $\mathrm{Al}_{2} \mathrm{O}_{3}$, and $\mathrm{Fe}_{2} \mathrm{O}_{3}$ in IOT, red mud, and GGBS were in the range of $9.01 \%$ to $37.73 \%, 9.56 \%$ to $25.05 \%$, and $1.11 \%$ to $45.66 \%$.

The physical properties of red mud and IOT are shown in Table 2. In accordance with ASTM C33, D854, and D4318 standards, the fineness modulus, specific gravity, and consistency limits were determined. ASTM D698 was used to determine the optimum moisture content and maximum dry density of the red mud and IOT.

\section{Brick Making with Red Mud and Iron Ore Tailings}

The mix proportion details are mentioned in Tables 3 and 4. In the present study, the stabilised blocks were made by manually operated block making machine "Mardini" designed by ASTRA/Department of Civil Engineering, Indian Institute of Science, Bangalore. $230 \times 110 \times 100 \mathrm{~mm}$ standard mould size was used for making of bricks.

Table 5 presents the details of the test specifications of IS and ASTM standards for testing the bricks.

\section{Results and Discussion}

Figures 5 and 6 show the SEM micrographs of iron ore tailings and red mud (RM), and the micrographs show irregular particles of high degree of agglomeration. Figure 7 illustrates a nonuniform distribution of irregular particles in GGBS. Figure 8 illustrates the XRD pattern of the RM with the combination of $\mathrm{Na}_{5} \mathrm{Al}_{3} \mathrm{CSi}_{3} \mathrm{O}_{15}(\mathrm{Na})$, calcium carbonate
$\left(\mathrm{Ca}\left(\mathrm{CO}_{3}\right)\right)$, muscovite $(\mathrm{M})$, hematite $(\mathrm{H})$, and aluminum hydroxide $\left(\mathrm{Al}\left(\mathrm{OH}_{3}\right)\right)$. Figure 9 shows the XRD pattern of the IOT and the presence of minerals such as quartz $(\mathrm{Q})$, kaolinite $(\mathrm{K})$, calcite $(\mathrm{C})$, and hematite $(\mathrm{H})$. Figure 10 shows the XRD pattern of GGBS signifying as amorphous material.

Table 6 depicts the apparent specific porosity, apparent specific gravity, bulk density, water absorption, and compressive strength of bricks.

The porosity of iron ore tailings geopolymer bricks ranged from $14.6 \%$ to $25.4 \%$ and for red mud geopolymer bricks ranged from $14.28 \%$ to $36.4 \%$ (Figure 11 ). This has not shown the significant influence on the compressive strength. The density of brick has not been significantly influenced by the varying percentages of iron ore tailings and red mud.

The compressive strength was higher for IOT geopolymer bricks in comparison to the compressive strength of RM geopolymer bricks. The compressive strength of IOT geopolymer bricks ranged from $17.27 \mathrm{~N} / \mathrm{mm}^{2}$ to $28.23 \mathrm{~N} /$ $\mathrm{mm}^{2}$. Mix-3I with $70 \%$ of IOT has exhibited the highest strength, as shown in Figure 12. From Figure 12, it was observed that the compressive strength of RM geopolymer bricks range from $8.3 \mathrm{~N} / \mathrm{mm}^{2}$ to $16.67 \mathrm{~N} / \mathrm{mm}^{2}$. Mix-3R with $70 \%$ of red mud has attained the highest compressive strength with an increment of 50.2\%. Both IOT and RM geopolymer bricks have been confirmed as high-quality bricks. Figure 13 presents that the water absorption for all the mix compositions is less than $20 \%$ and the values are as per IS code recommendations. The efflorescence results of all the compositions fulfill the standards of IS: 3495-Part [3]. From Figure 14, it is evident that there is no significant variation of specific gravity for varying percentages of iron ore tailings and red mud.

4.1. SEM Analysis. Figures 15-18 present the morphology of the mixes $1 \mathrm{I}, 3 \mathrm{I}, 1 \mathrm{R}$, and $3 \mathrm{R}$. Heterogeneous nature of the final compounds has been unambiguously proved from the micrographs. All the systems contain some amount of shapeless independent particles with high degree of aggregation. Aggregation may be a result of processing conditions, which has some influence on the strength and stability of the systems. Along with the highly aggregated surface structure, some inconspicuous numbers of rod, such as morphologies, were observed in the micrographs of the compounds $3 \mathrm{R}$ and $1 \mathrm{R}$. X-ray fluorescence associated with SEM analysis was used to understand the composition of the systems qualitatively.

4.2. X-Ray Diffraction Results. Figures 19-22 present the XRD analysis of the mixes $1 \mathrm{I}, 3 \mathrm{I}, 1 \mathrm{R}$, and 3R.The X-ray diffraction patterns of the compounds $1 \mathrm{I}$ and 3Iare almost the same. However, some extrapeaks were observed in mix1I compared to Mix-3I, due to higher concentration of IOT in mix-1I. The high concentration of IOT might have facilitated the exposure of hematite crystal planes for diffraction and also the comparatively high concentration of GGBS in Mix-3I would have suppressed the crystal planes from diffraction process. The patterns revealed the existence of crystalline compounds as the major constituents of the 
TABle 1: Chemical composition IOT, red mud, and GGBS.

\begin{tabular}{|c|c|c|c|c|c|c|c|c|c|}
\hline Materials & $\mathrm{SiO}_{2}(\%)$ & $\mathrm{Al}_{2} \mathrm{O}_{3}(\%)$ & $\mathrm{Fe}_{2} \mathrm{O}_{3}(\%)$ & $\mathrm{TiO}_{2}(\%)$ & $\mathrm{CaO}(\%)$ & $\mathrm{MgO}(\%)$ & $\mathrm{Na}_{2} \mathrm{O}(\%)$ & $\mathrm{K}_{2} \mathrm{O}(\%)$ & Loi (\%) \\
\hline IOT & 9.02 & 9.56 & 45.66 & 1.02 & 1.96 & 2.12 & 0.93 & 0.25 & 8.59 \\
\hline Red mud & 22.63 & 25.05 & 23.03 & 7.01 & 1.26 & 1.72 & 6.83 & 0.22 & 12.21 \\
\hline GGBS & 37.73 & 14.42 & 1.11 & 37.34 & 8.71 & 0.02 & 0.31 & 0.29 & 1.41 \\
\hline
\end{tabular}

TABle 2: Physical properties of IOT and red mud.

\begin{tabular}{lcc}
\hline Properties & Red mud & Iron ore tailings \\
\hline Plastic limit & $27 \%$ & $16.56 \%$ \\
Liquid limit & $46 \%$ & $26.1 \%$ \\
Plasticity index & 19 & 9.54 \\
Maximum dry density & $1.48 \mathrm{~kg} /$ cubic & $2.14 \mathrm{~kg} /$ cubic \\
Optimum moisture & meter & meter \\
content & $14.95 \%$ & $9.8 \%$ \\
Specific gravity & 2.8 & 2.34 \\
\hline
\end{tabular}

TABle 3: Details of the mix proportions of red mud bricks.

\begin{tabular}{lcc}
\hline Brick designation & Red mud (\%) & GGBS (\%) \\
\hline Mix 1R & 90 & 10 \\
Mix 2R & 80 & 20 \\
Mix 3R & 70 & 30 \\
Mix 4R & 60 & 40 \\
Mix 5R & 50 & 50 \\
\hline
\end{tabular}

TABLE 4: Details of the mix proportions of iron ore tailings bricks.

\begin{tabular}{lcc}
\hline Brick designation & Iron ore tailings (\%) & GGBS (\%) \\
\hline Mix 1I & 90 & 10 \\
Mix 2I & 80 & 20 \\
Mix 3I & 70 & 30 \\
Mix 4I & 60 & 40 \\
Mix 5I & 50 & 50 \\
\hline
\end{tabular}

TABle 5: Details of the test specification

\begin{tabular}{lc}
\hline : Test method & Standards \\
\hline Compressive strength & IS 1077-1992 \\
Water absorption & IS 3495 (part 2):1992 \\
Apparent porosity & ASTM C20 \\
Apparent specific gravity & ASTM C20 \\
Bulk density & ASTM C20 \\
\hline
\end{tabular}

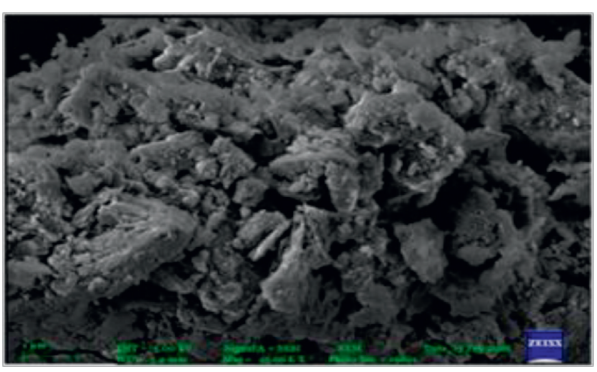

FIGURE 5: SEM micrograph of IOT.

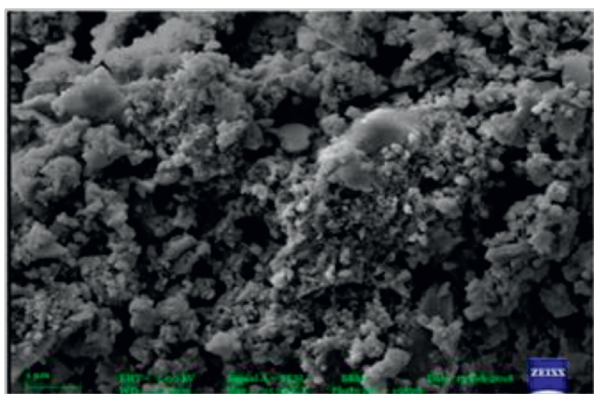

FIgURE 6: SEM micrograph of RM.

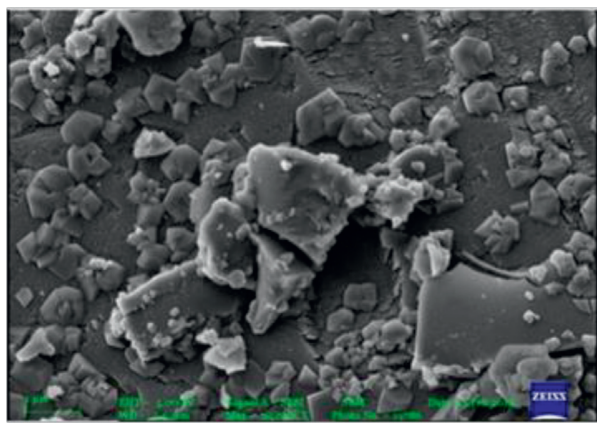

FIGURE 7: SEM micrograph of GGBS.

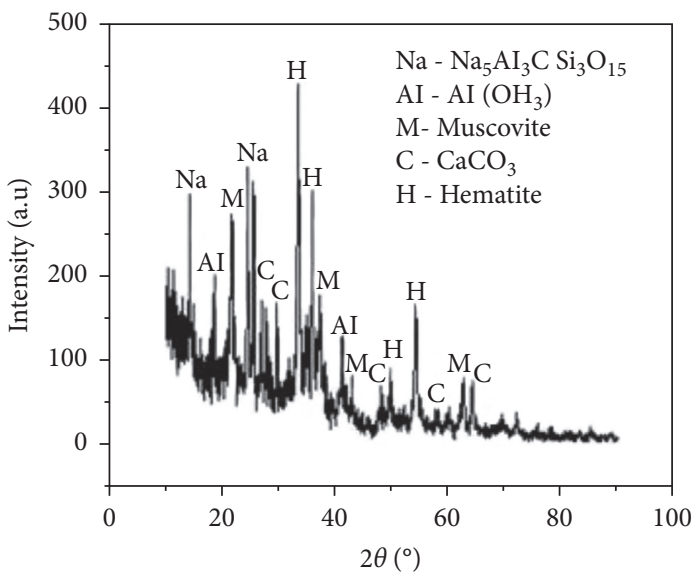

FIgURE 8: XRD pattern of RM.

final systems. Silica, alumina, and hematite were the major compounds observed with minor quantities of Titania, calcium oxide, and magnesium oxide. Well-resolved peaks with low full width at half maximum (FWHM) confirmed the presence of crystallites or grains with large size, which is well in agreement with the SEM analysis. Small crystallites 


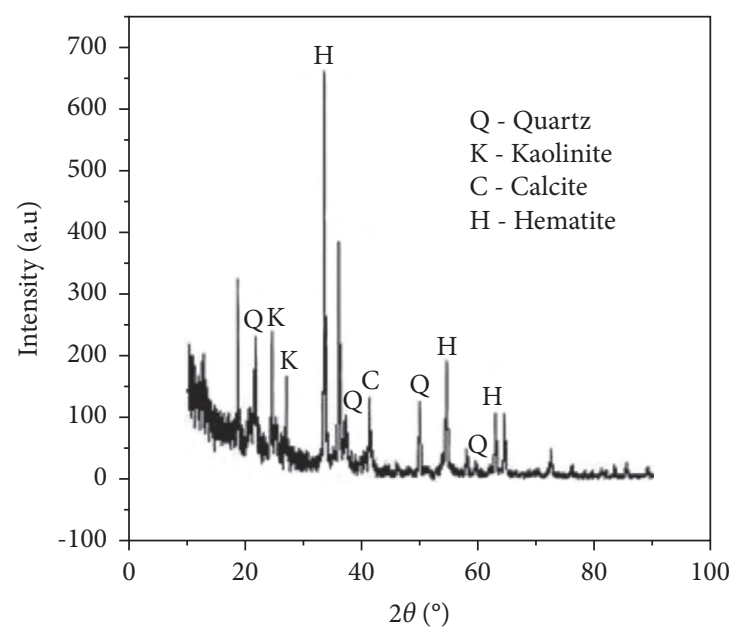

Figure 9: XRD pattern of IOT.

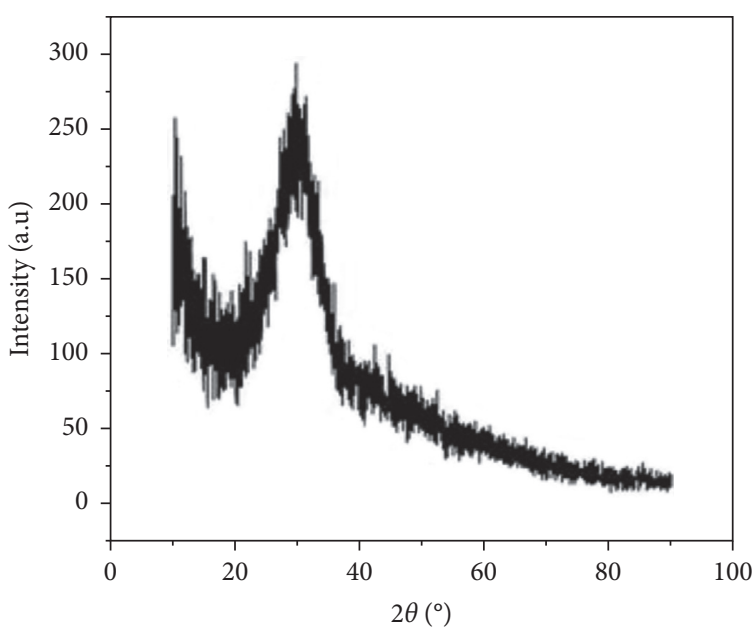

Figure 10: XRD pattern of GGBS.

TABLE 6: Apparent porosity, apparent specific gravity, bulk density, water absorption, and compressive strength

\begin{tabular}{lcccccc}
\hline Composition & $\begin{array}{c}\text { Apparent } \\
\text { porosity }(\%)\end{array}$ & $\begin{array}{c}\text { Apparent } \\
\text { specific gravity }\end{array}$ & $\begin{array}{c}\text { Bulk density } \\
\left(\mathrm{g} / \mathrm{cm}^{3}\right)\end{array}$ & $\begin{array}{c}\text { Water } \\
\text { absorption }(\%)\end{array}$ & $\begin{array}{c}\text { Compressive strength } \\
\left(\mathrm{N} / \mathrm{mm}^{2}\right)(7 \text { Days })\end{array}$ & $\begin{array}{c}\text { Compressive strength (N/ } \\
\left.\mathrm{mm}^{2}\right)(28 \mathrm{Days})\end{array}$ \\
\hline Mix-1I & 14.6 & 1.48 & 1.26 & 3.78 & 11.25 & 17.27 \\
Mix-2I & 17.25 & 1.38 & 1.11 & 4.53 & 17.43 & 27.01 \\
Mix-3I & 18.2 & 1.3 & 1.08 & 4.98 & 21.26 & 28.23 \\
Mix-4I & 20.32 & 1.25 & 1.03 & 5.81 & 15.1 & 23.54 \\
Mix-5I & 25.4 & 1.2 & 0.97 & 7.58 & 5.92 & 8.3 \\
Mix-1R & 14.28 & 1.41 & 1.02 & 8.96 & 12.25 & 11.06 \\
Mix-2R & 21.25 & 1.33 & 0.93 & 9.25 & 10 & 16.67 \\
Mix-3R & 24.17 & 1.24 & 0.88 & 9.86 & 10.25 & 14.22 \\
Mix-4R & 33.33 & 1.13 & 0.78 & 10.64 & 12.64 \\
Mix-5R & 36.4 & 1.06 & 0.64 & 10.4 & & \\
\hline
\end{tabular}

may have combined together under the processing conditions and could have facilitated the high degree of aggregation or the formation of grains/crystallites with large size. Some compounds were not observed either due to the less exposure of crystal planes due to the complexity of the system or due to the amorphous nature. The peak observed at $2 \theta=7^{\circ}$ was assigned to the alumina content of the zeolite
[27]. The sharp and intense peaks at $2 \theta$ values around $17.4^{\circ}$, $34^{\circ}, 39.5^{\circ}, 48^{\circ}$, and $75^{\circ}$ were attributed to the miller planes corresponding to mullite [28]. A less intense peat $28^{\circ}$ was indexed to the (110) reflections of rutile $\mathrm{TiO} 2$ [29]. Peaks around $33^{\circ}$ and $36^{\circ}$ were allocated to the crystal planes of hematite [30]. Dominant peak observed at $2 \theta=29.1^{\circ}$ was indexed to the crystal plane of calcite [31]. Highly intense 


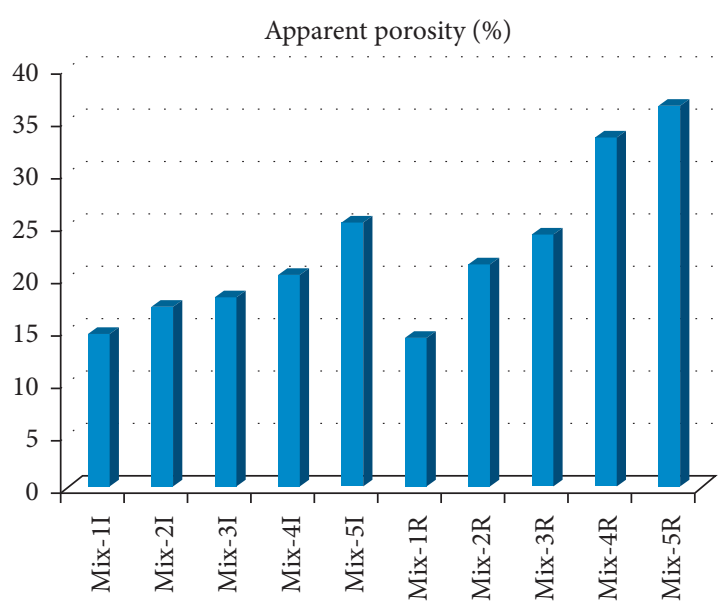

- Apparent porosity (\%)

FIgURE 11: Apparent porosity of bricks.

Compressive strength $\left(\mathrm{N} / \mathrm{mm}^{2}\right)$

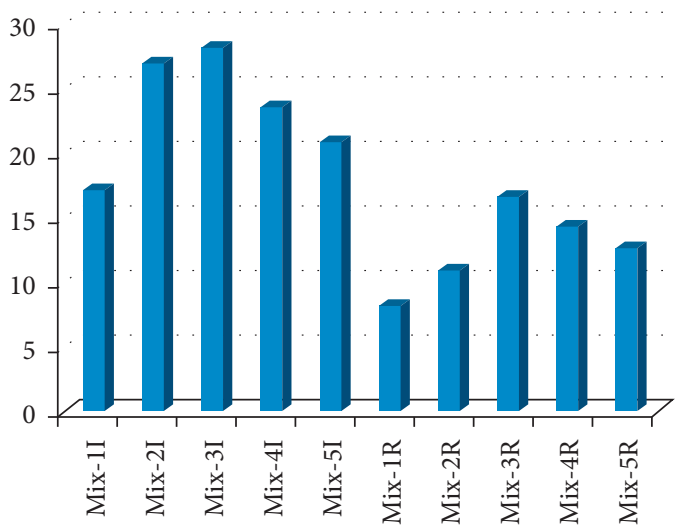

- Compressive strength $(\mathrm{N} / \mathrm{mm} 2)$

FIgURE 12: Compressive strength of bricks.

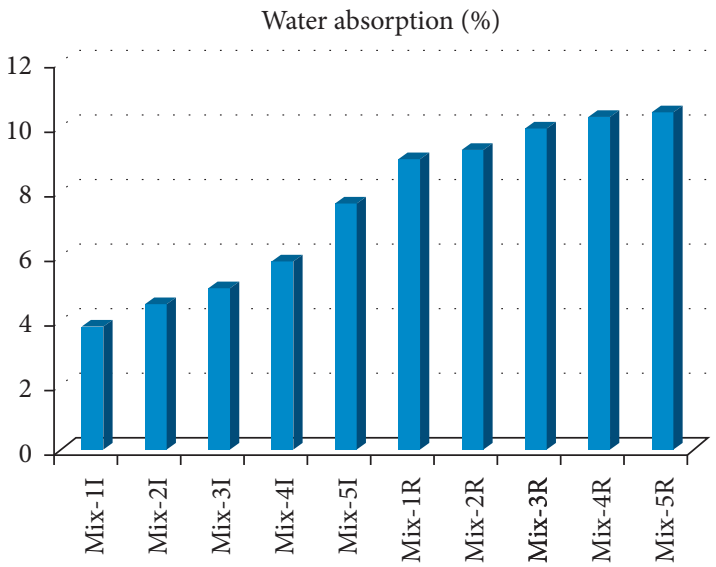

Water absorption (\%)

FIgURE 13: Water absorption of bricks.

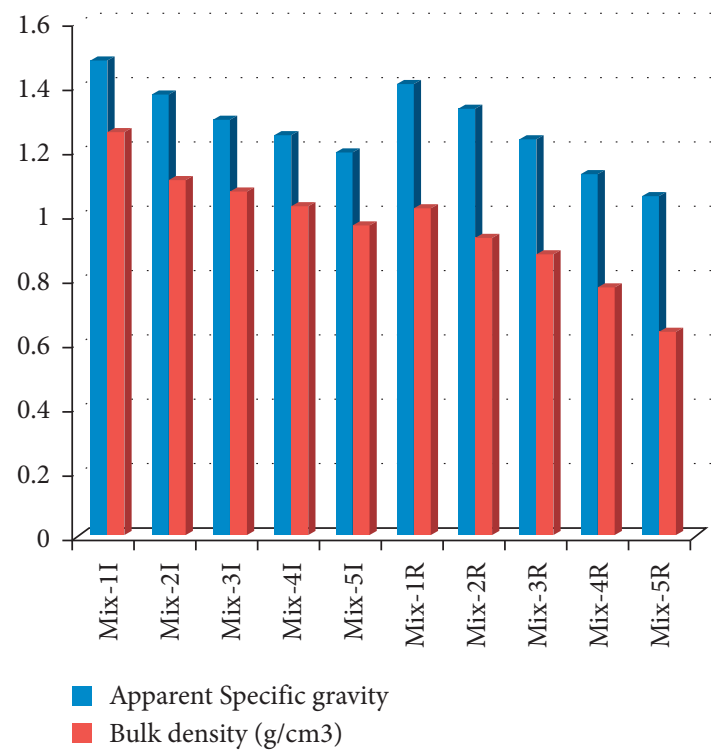

FIGURE 14: Apparent specific gravity and Bulk density.

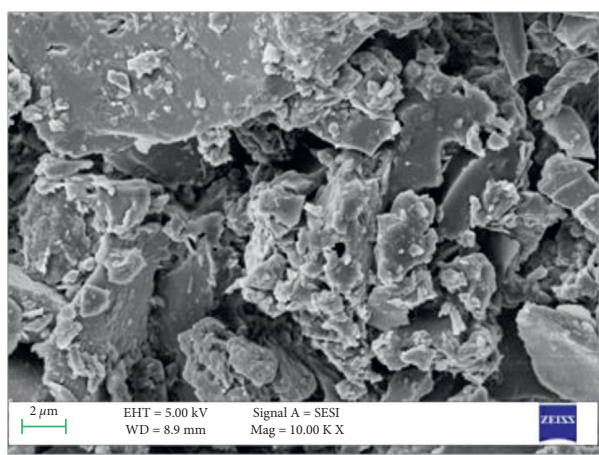

FIgURE 15: SEM image of Mix-1I.

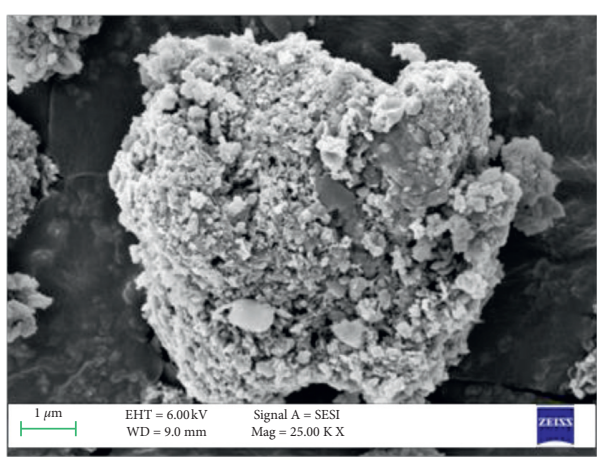

Figure 16: SEM image of Mix-3I.

peaks at $27^{\circ}, 43^{\circ}, 50^{\circ}, 55^{\circ}$, and $60^{\circ}$ were attributed to the crystal plane reflections of quartz [27, 28, 32]. Generally, a broad peak in the range of $2 \theta=20^{\circ}$ to $40^{\circ}$ with large full width at half maximum indicates the amorphous nature of GGBS [32]. The peak of GGBS was not observed, which might be due to the overlapping of the peak with other peaks in the range. Some extra peaks at $2 \theta=57^{\circ}, 62.1^{\circ}, 64.3^{\circ}$, and $73.8^{\circ}$ 


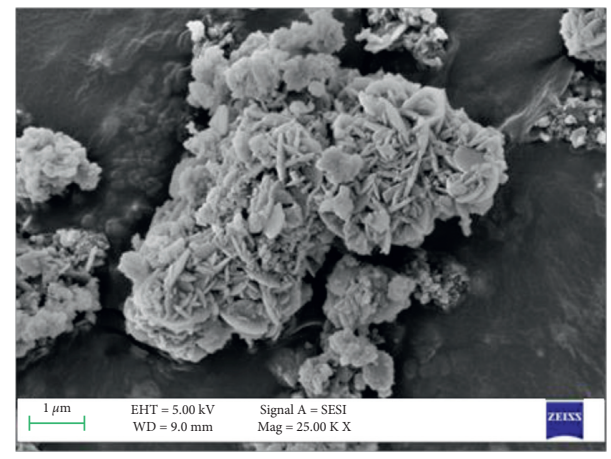

Figure 17: SEM image of Mix-1R.

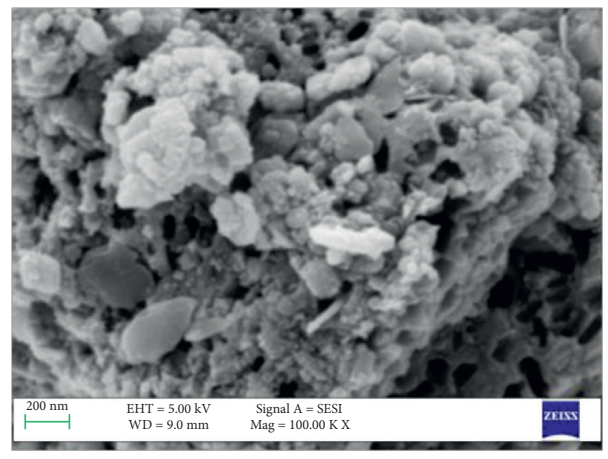

Figure 18: SEM image of Mix-3R.

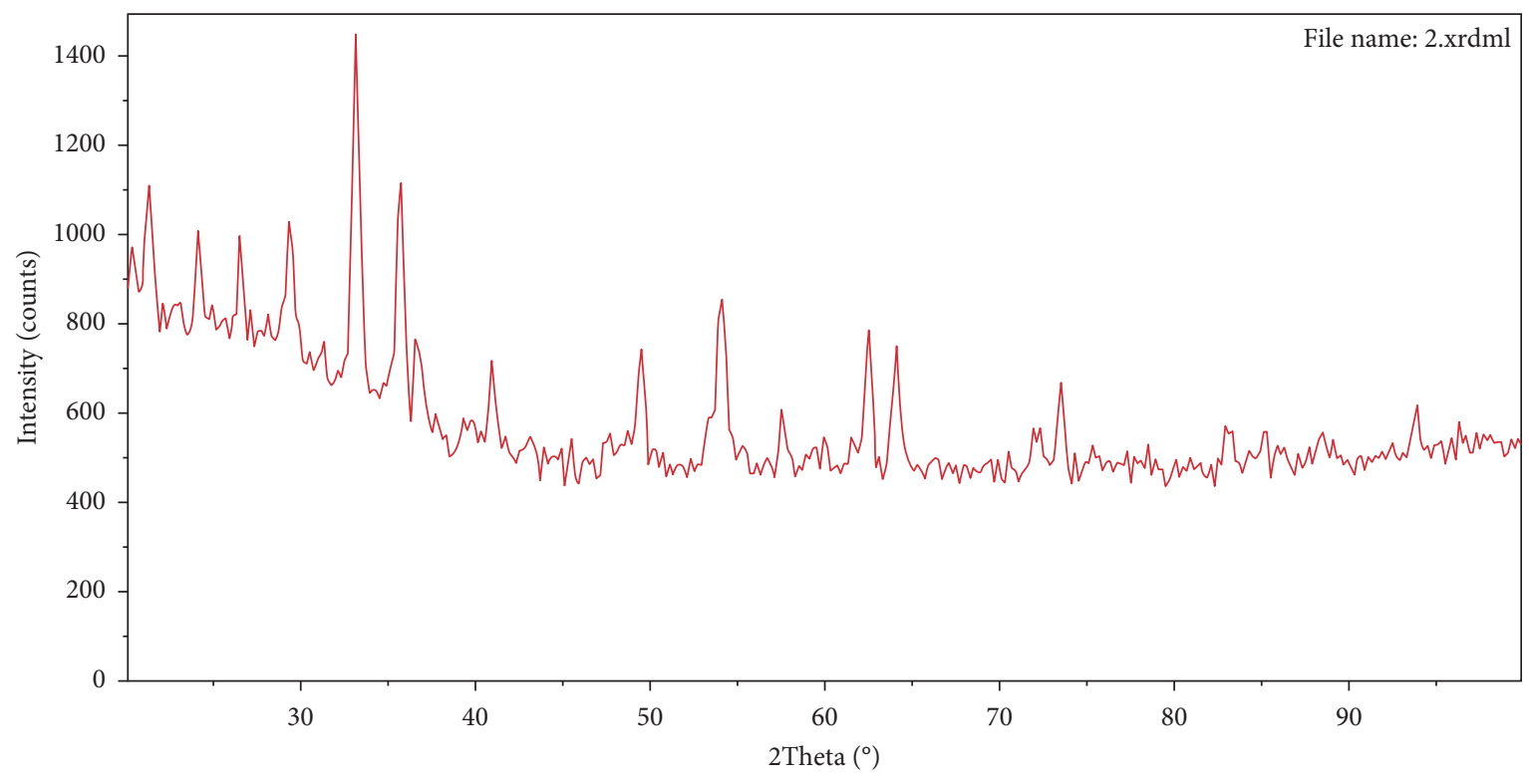

FIgURE 19: XRD image of Mix-1I.

were observed in mix-1I compared to Mix-3I. The peak at $2 \theta$ around 57 owas assigned to the crystal plane of quartz, and the peaks at $2 \theta$ around $62.1^{\circ}, 64.3^{\circ}$, and $73.8^{\circ}$ were allocated to the miller planes of hematite. The high concentration of IOT in mix-1I exposed more crystal planes of hematite for diffraction but the mentioned crystal planes were not exposed in Mix-3I due to less concentration.
The XRD patterns of the compounds $1 \mathrm{R}$ and $3 \mathrm{R}$ are more or less the same.Some extrapeaks were observed in Mix-1R compared to the Mix-3R. Here also, the concentration of the constituents played an important role in diffraction process. Mix-1R contained more concentration of red mud compared to Mix-3R. Therefore, the former exhibited some additional peaks due to the diffraction from some additional 


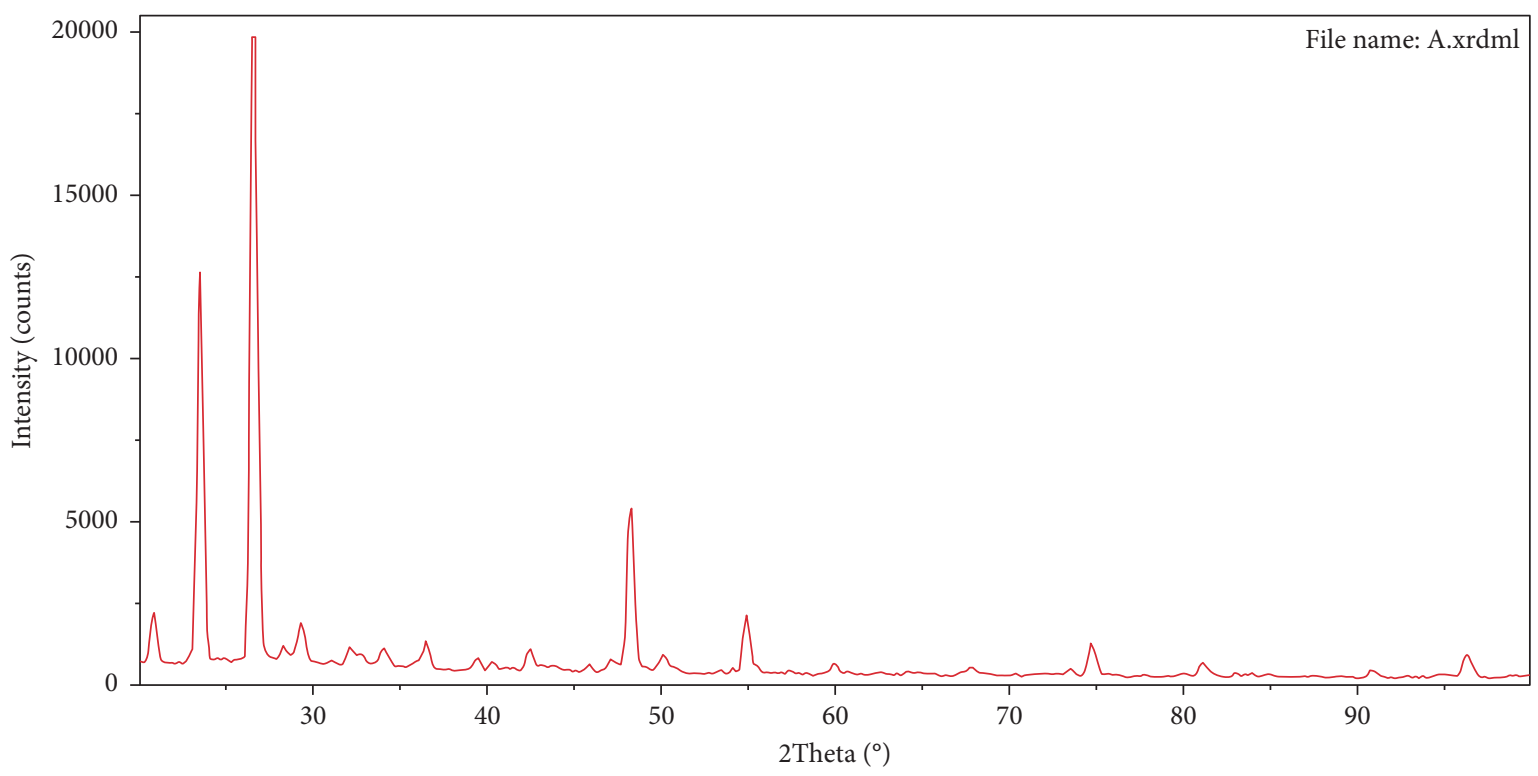

FIgURE 20: XRD image of Mix-3I.

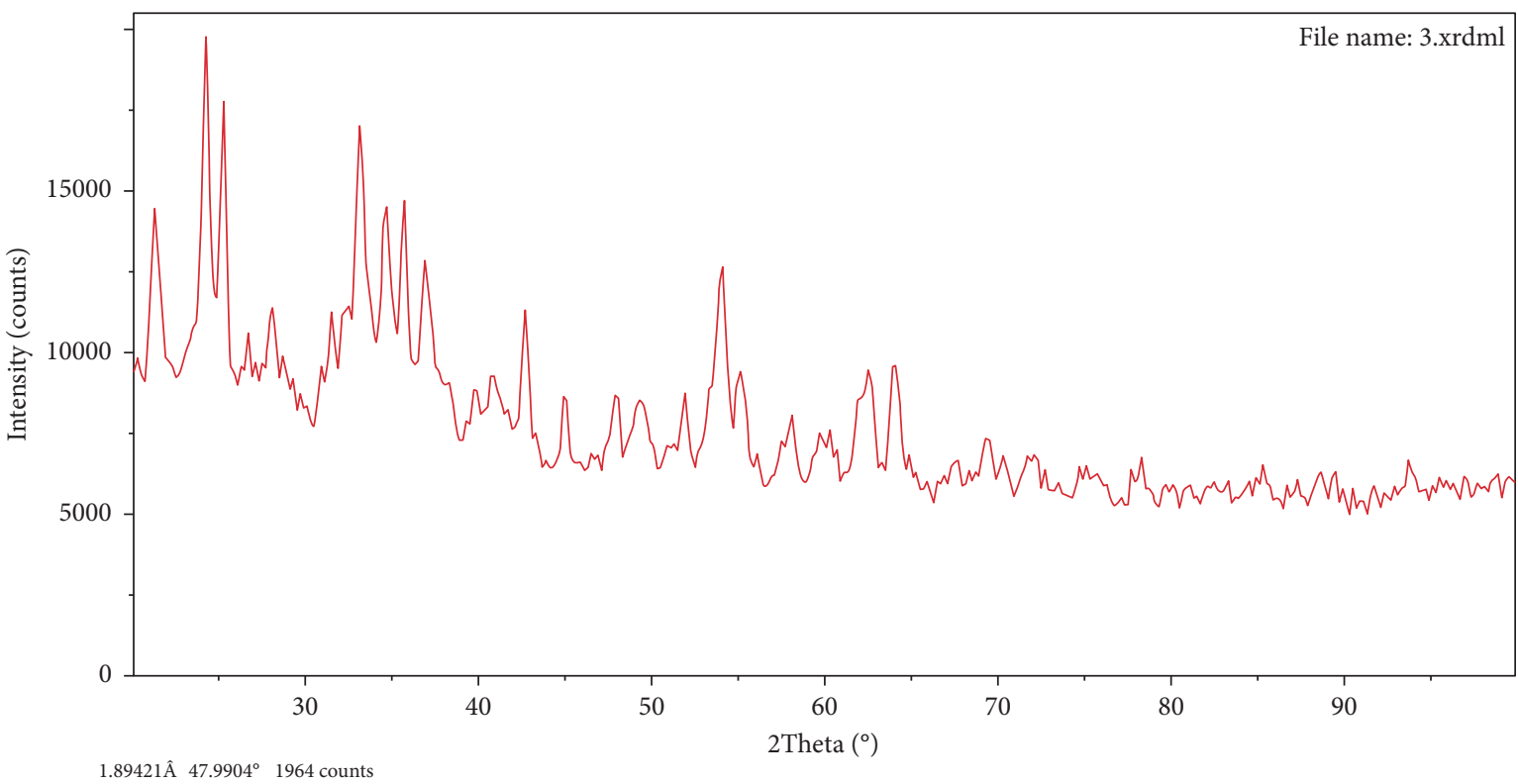

FIgURE 21: XRD image of Mix-3R.

crystal planes. The high concentration of GGBS in Mix-3R is considered as a constraint for the effective diffraction process. Here also, silica, alumina, and hematite were found to be the major compounds with less quantities of titania, calcium oxide, and magnesium oxide. All the compounds observed in the patterns of $1 \mathrm{R}$ and $1 \mathrm{I}$ were also observed in the case of $3 R$ and 3I with some variations of intensities and'd' spacing. Due to the high concentration of iron content, the peaks at $2 \theta=33^{\circ}$ and $36^{\circ}$ were found to be more dominant in $3 \mathrm{R}$ and $3 \mathrm{I}$ in comparison to the former compounds [30]. Also, the dominant peaks at $2 \theta$ values around $62^{\circ}, 64.2^{\circ}$, and $76.1^{\circ}$ in mix-1R were assigned to the crystal planes of hematite. Some crystal planes of hematite were not observed in mix-3R either due to the less concentration of red mud or the shielding effect of GGBS which results in less exposure of crystal planes for diffraction. A wellresolved peak around $84^{\circ}$ in Mix-1R was attributed to the crystal plane of quartz. The structural compositions of the compounds were evaluated thoroughly by XRD analysis. The results obtained were well in agreement with the XRF results. 


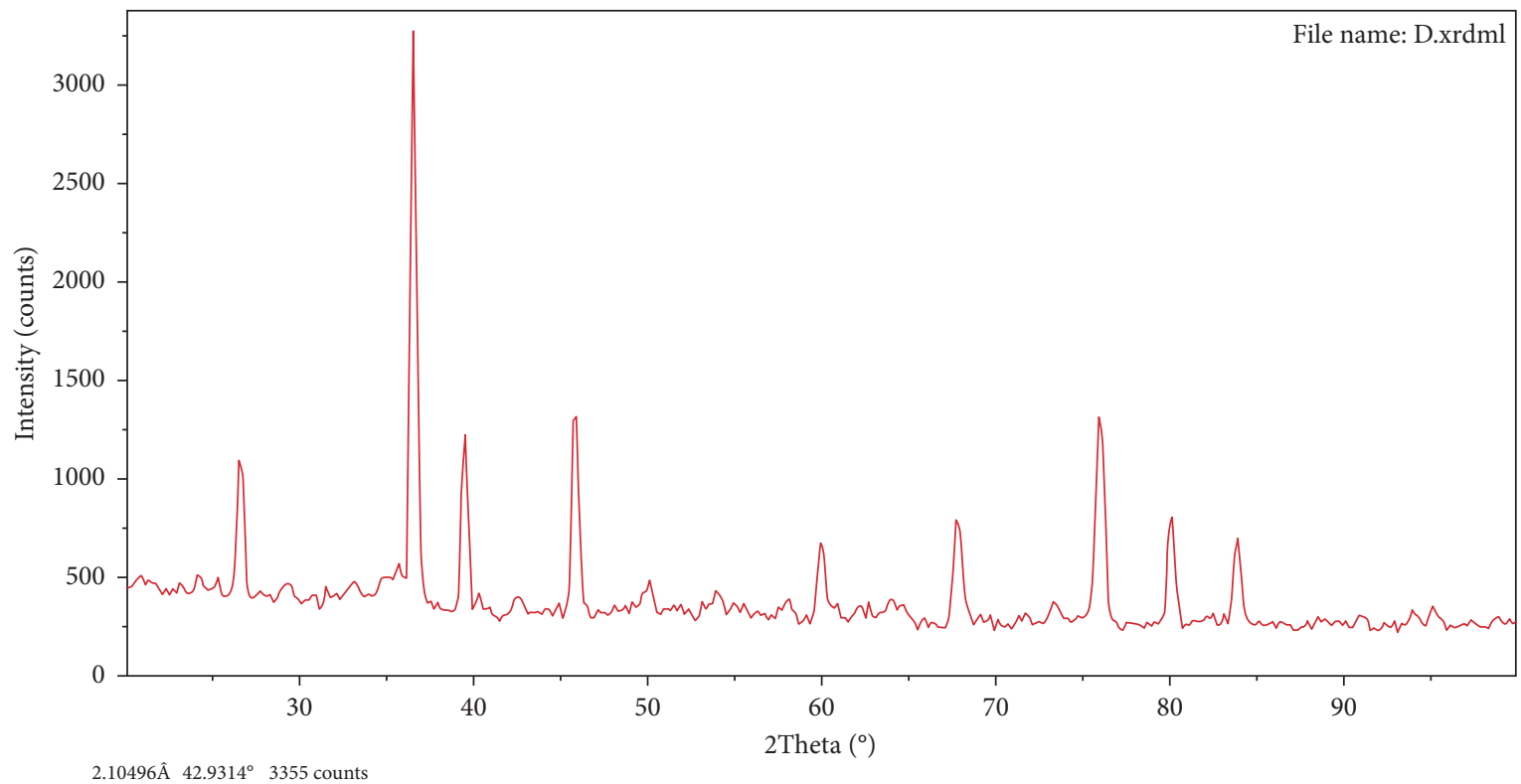

Figure 22: XRD image of Mix-1R.

\section{Conclusions}

The current study focused on the manufacturing of bricks made primarily of iron ore tailings and red mud. The following are the findings of the study:

(1) The compressive strength values showed noticeable differences in case of IOT and red mud bricks with IOT-based bricks showing better comprehensive strengths. It can be inferred that Mix-3I of IOT showed the highest value of compression strength $28.23 \mathrm{~N} / \mathrm{mm}^{2}$, a class 'A' brick.

(2) The compressive strength of brick increased with the increase in the curing period. Red mud and IOT bricks have attained desired compressive strength as per IS recommendations.

(3) The optimum mix of red mud bricks is $3 \mathrm{R}(70 \%$ $\mathrm{RM}+30 \% \mathrm{GGBS})$ and of IOT bricks is $3 \mathrm{I}(70 \%$ IOT+30\%GGBS).

(4) The soundness, hardness, efflorescence, and impact test results for all the compositions are within the Indian standard recommendations.

(5) The manufacture of bricks without using Kiln firing is a way to reduce the emission of $\mathrm{CO}_{2}$ gas. The results of the current study showed that the production of eco-friendly bricks by effective utilization of waste materials such as IOT, GGBS, and red mud with geopolymerization, is a proactive sustainability approach.

\section{Data Availability}

The data used to support the findings of this study are included within the article, and further data or information required are available from the corresponding author upon request.

\section{Disclosure}

It was performed as a part of the employment responsibilities at the Bule Hora University, Ethiopia.

\section{Conflicts of Interest}

The authors declare that they have no conflicts of interest.

\section{Acknowledgments}

The authors appreciate the supports from Christ (Deemed to be University), Bangalore, India, and Bule Hora University, Ethiopia, for the technical assistance to complete this experimental work.

\section{References}

[1] N. Gangadhara Reddy and B. Hanumantha Rao, "Evaluation of the compaction characteristics of untreated and treated red mud," Geo-Chicago, vol. 273, 2016.

[2] V. Jiménez-Quero, O. T. Maza-Ignacio, J. Guerrero-Paz, and $\mathrm{K}$. Campos-Venegas, "Industrial wastes as alternative raw materials to produce eco-friendly fired bricks," Journal of Physics: Conference Series, vol. 792, Article ID 012065, 2017.

[3] R. Kumar, P. Das, M. Beulah, and H. R. Arjun, "Geopolymer bricks using iron ore tailings, Slag sand, ground granular blast furnace Slag and fly ash," Geopolymers and Other Geosynthetics, vol. 64347, 2020.

[4] V. Sabat, M. Shaikh, M. Kanap, and K. Knadgouda, "Use of iron ore tailings as a construction material," International Journal of Conceptions on Mechanical and Civil Engineering, vol. 3, no. 2, pp. 1-6, 2015.

[5] F. A. Kuranchie, S. K. Shukla, D. Habibi, and A. Mohyeddin, "Utilisation of iron ore tailings as aggregates in concrete," Cogent Engineering, vol. 2, no. 1, Article ID 1083137, 2015.

[6] S. R. Lamani, M. Aruna, and H. Vardhan, A. T. Shanth, Development of value added product using iron ore waste for 
its effective utilization," International Journal of Advanced and Applied Sciences, vol. 2, no. 12, pp. 30-35, 2015.

[7] F. A. Kuranchie, S. K. Shukla, and D. Habibi, "Utilisation of iron ore mine tailings for the production of geopolymer bricks," International Journal of Mining, Reclamation and Environment, vol. 30, no. 2, pp. 92-114, 2016.

[8] M. R. Sudhir, M. Beulah, P. Sasha Rai, and G. Gayathri, “A microstructure exploration and compressive strength determination of red mud bricks prepared using industrial wastes," Materials Today: Proceedings, vol. 46, pp. 163-169, 2021.

[9] C. Nivetha and R. Johnson Daniel, "Study on strength and behaviour of red mud bricks"," Journal of Industrial Pollution Control, vol. 33, no. 2, pp. 1227-1230, 2007.

[10] P. A. Mohamed Najar, M. T. Nimje, and S. K. S. Prajapati, "Development of Light weight foamed bricks from red mud," in Proceedings of the Conference: IBAAS, Nagpur, India, December 2012.

[11] S. Singh, S. N. Basavanagowda, M. U. Aswath, and R. V. Ranganath, "Durability of bricks coated with red mud based geopolymer paste," IOP Conference Series: Materials Science and Engineering, vol. 149, Article ID 012070, 2016.

[12] B. Garhard, "Method for producing bricks from red mud," US patent 3886244, 1975.

[13] A. Dass and S. K. Malhotra, "Lime-stabilized red mud bricks," Materials and Structures, vol. 23, no. 4, pp. 252-255, 1990.

[14] D. D. Dimas, I. P. Giannopoulou, and D. Panias, "Utilization of alumina red mud for synthesis of inorganic polymeric materials," Mineral Processing and Extractive Metallurgy Review, vol. 30, no. 3, pp. 211-239, 2009.

[15] N. Peter, Making Bricks with Red Mud in Jamaica, International Development Research Centre, IDRC Reports, no. 2, Ottawa, Canada, 1997.

[16] K. Sethy, R. K. Sitha, S. Barpanda, and B. R. Bhoi, "Experimental investigation of strength properties of red mud concrete," in Proceedings of the International Conference on Sustainable Materials and Structures for Civil Infrastructures (SMSCI2019), Bhopal, Madhya Pradesh, India, September 2019.

[17] S. Rai, K. L. Wasewar, M. J. Chaddha, and J. Mukhopadhyay, "Utilization of red mud for making bricks," Research Journal of Engineering and Technology, vol. 4, no. 1, pp. pp12-14, 2013.

[18] M. Bhaskar, S. Akhtar, and G. Batham, "Development of the bricks from red mud by industrial waste (red mud)," International Journal of Emerging Science and Engineering, vol. 2, no. 4, pp. 7-12, 2014.

[19] D. Dodoo-Arhin, R. A. Nuamah, B. Agyei-Tuffour, D. O. Obada, and A. Yaya, "Awaso bauxite red mud-cement based composites: characterisation for pavement applications," Case Studies in Construction Materials, vol. 7, pp. 45-55, 2017.

[20] J. Z. Qi, J. Yang, M. Wang, and B. Xiao, Experimental Research on Road Materials of Red Mud, University of Huazhong Science and Technology, Wuhan, China, 2005.

[21] P. K. Ghosh, Utilization of Aluminium Waste and Pond Ash for Construction of Embankments, Btech thesis submitted to NIT, Rourkela, India, 2009.

[22] L. G. Yang, Z. L. Yao, and D. S. Bao, "Pumped and cemented red mud slurry filling mining method (In Chinese)," Mining Research and Development, no. 16, pp. 18-22, 1996.

[23] C. Klauber, M. Gräfe, and G. Power, Review of bauxite residue re-use options, CSIRO Minerals, Waterford, WA, 2009.

[24] Y. Pontikes and G. N. Angelopoulos, "Bauxite residue in cement and cementitious applications: current status and a possible way forward," Resources, Conservation and Recycling, vol. 73, pp. 53-63, 2013.
[25] M. Beulah, K. Sarath Chandra, M. K. Mohan, I. Clifford Dean, and G. Gayathri, "An experimental study on utilisation of red mud and iron ore tailings in production of stabilised blocks," Sustainable Civil Engineering Practices, Springer, Berlin, Germany, pp. 9-19, 2020.

[26] M. S. S. Lima, L. P. Thives, V. Haritonovs, and K. Bajars, "Red mud application in construction industry: review of benefits and possibilities," IOP Conference Series: Materials Science and Engineering, vol. 251, Article ID 012033, 2017.

[27] M. Gougazeh and J.-C. Buhl, "Synthesis and characterization of zeolite A by hydrothermal transformation of natural Jordanian kaolin," Journal of the Association of Arab Universities for Basic and Applied Sciences, vol. 15, no. 1, pp. 35-42, 2014.

[28] P. P. Nampi, P. Moothetty, F. J. Berry, M. Mortimer, and K. G. Warrier, "Aluminosilicates with varying alumina-silica ratios: synthesis via a hybrid sol-gel route and structural characterisation," Dalton Transactions, vol. 39, no. 21, p. 5101, 2010.

[29] J. He, Y.-e. Du, Y. Bai et al., "Facile formation of anatase/rutile TiO2 nanocomposites with enhanced photocatalytic activity," Molecules, vol. 24, no. 16, Article ID 2996, 2019.

[30] Z. Ž. Lazarević, Č. Jovalekić, A. Milutinović, M. J. Romčević, and N. Ž. Romčević, "Preparation and characterization of nano ferrites," Acta Physica Polonica A, vol. 121, no. 3, pp. 682-686, 2012.

[31] A. Linggawati, "Preparation and characterization of calcium oxide heterogeneous catalyst derived from anadara granosa shell for biodiesel synthesis," KnE Engineering, vol. 1, no. 1, 2016.

[32] P. E. Stutzman, J. W. Bullard, and P. Feng, "Phase Analysis of portland cement by combined quantitative X-ray powder diffraction and scanning electron microscopy," Journal of Research of the National Institute of Standards and Technology, vol. 121, pp. 47-107, 2016. 